\title{
NECTAR OF Ziziphus spina-christi (L.) WILLD (Rhamnaceae): DYNAMICS OF SECRETION AND POTENTIAL FOR HONEY PRODUCTION
}

\author{
Adgaba Nuru', Awad M. Awad ${ }^{2}$, \\ Ahmad A. Al-Ghamdi ${ }^{1}$, \\ Abdulaziz S. Alqarni ${ }^{2}$, Sarah E. Radloff ${ }^{3}$ \\ ${ }^{1}$ Chair of Engineer Abdullah Baqshan, for Bee Research, Department of Plant Protection, \\ Faculty of Food and Agriculture Science, King Saud University, Riyadh, Saudi Arabia \\ ${ }^{2}$ Department of Plant Protection, Faculty of Food Science and \\ Agriculture, King Saud University, Riyadh, Saudi Arabia \\ ${ }^{3}$ Department of Statistics, Rhodes University, Grahamstown, South Africa \\ e-mail: nuruadgaba@gmail.com \\ Received 11 April 2012; accepted 29 August 2012 \\ $\mathrm{S}$ u m m a r y
}

The nectar secretion of Ziziphus flowers was studied by removing and measuring the nectar every four hours, for two consecutive days, from 88 flowers of four trees ('repeated sampling'). In another 120 flowers from the same trees, the accumulated sugar was measured at the end of the flowering stage. The mass of the nectar sugar was determined following the washing technique. The total amount of sugar per tree was calculated by multiplying the number of flowers per tree by the average mass of nectar sugar secreted per flower. The average mass of sugar produced per flower in repeated sampling was $0.79 \pm 0.54 \mathrm{mg} /$ flower (range $0.09-2.48 \mathrm{mg}$ ). The average mass of sugar per flower for each of the four investigated trees was $1.43 \pm 0.53 \mathrm{mg}, 0.72 \pm 0.27 \mathrm{mg}, 0.94 \pm 0.39 \mathrm{mg}$ and $0.37 \pm 0.26 \mathrm{mg}$, respectively. The differences among trees was statistically significant. For accumulated nectar, the overall average mass of sugar per flower was $0.55 \pm 0.23 \mathrm{mg}$ (range $0.06-1.29 \mathrm{mg}$ ) and the average values for flowers on the investigated trees of $Z$. spina-christi were $0.69 \pm 0.26 \mathrm{mg}, 0.41 \pm 0.16 \mathrm{mg}$, $0.51 \pm 0.16 \mathrm{mg}$ and $0.53 \pm 0.21 \mathrm{mg}$; these variations were statistically significant. The average mass of nectar sugar calculated for the flowers with accumulated nectar sampling was significantly lower than the average mass of sugar recorded for repeated nectar sugar samplings $(0.79 \pm 0.54 \mathrm{mg})$. According to this study, one Ziziphus tree is estimated to produce $3.6 \mathrm{~kg}$ of honey (range 2.2 $5.2 \mathrm{~kg}$ ), equivalent to about $900 \mathrm{~kg}$ of honey/ha (range $550-1300 \mathrm{~kg}$ ). These figures indicate the high potential value of the plant for honey production. Nectar secretion was positively correlated with temperature, indicating the adaptation of the tree to hot climates.

Keywords: nectar secretion, nectar sugars concentration, melliferous plant,

\section{Ziziphus spina-christi.}

\section{INTRODUCTION}

A bee plant's contribution to honey production depends not only on its abundance but also on its nectar quality and quantity. Moreover, not all nectar produced by flowers is accessible to honeybees (Bastiaan, 1984). Even if accessible, the amount and concentration of nectar varies from plant to plant, and over time (Roubik, 1991; Chalcoff et al.,
2006). Many studies have been conducted on different species to quantify nectar secretion and to explore its dynamics, mainly in relation to pollination biology, phenology and biophysical factors of the environment (e.g. Petanidou and Smets, 1996; Castellanos et al., 2002; Galetto and Bernardello, 2004). Quantitative studies on nectar secretion of melliferous plants include those of Pesti (1976), 
Mohr and Jay (1990), Nepi et al. (2001), Farkas and Orosz-Kovács (2003), Horváth and Orosz-Kovács (2004) and Zajácz et al. (2006).

Based on detailed studies of the dynamics of nectar secretion and its amount and sugar concentration, it was possible to estimate the honey production potentials of some important honey source plants like Asclepias syriaca L. (milkweed) (500-600 kg honey/ha/flowering season; Zsidei, 1993); Trifolium pratense L. (red clover) (883 kg of sugar/ha/flowering season; Szabo and Najda, 1985); Phacelia tanacetifolia Benth (60-360 kg honey/ha/flowering season; Nagy, 2002). Moreover, Crane et al. (1984) reported the honey production potential of different Tilia (lime) species ranging from 90 to $1200 \mathrm{~kg}$ honey/ha. Recently, Kim et al. (2011) quantified the amount of nectar secreted per flower and also per tree for Crataegus pinnatifida Bunge (Chinese hawthorn).

However, there are still many important melliferous plants for which nectar secretion and its significance for honey production have not yet been documented. These plants include one of the most important melliferous species, Ziziphus spina-christi. This species grows in a wide range of habitats covering vast land areas from North West Africa to East Africa, through the Sahara and Sahelian zones into the Eastern Mediterranean, the Arabian Peninsula, Iran, Turkey, and up to Western and Tropical Asia (Scholte et al., 1991; Orwa et al., 2009). The plant grows naturally in 16 African countries (NAS, 1980) and in 13 Asian countries (Scholte et al., 1991). It is one of the most drought and heat tolerant plant species, commonly found in an altitude range from 0 to 2000 m.a.s.l., and is adapted to high temperatures and low rainfall (Orw a et al., 2009). The tree is widely used to produce a range of products: food, fodder, fuel, drink, timber, medicine and more. It is also widely used to protect against soil erosion, and as a shade tree (Orwa et al., 2009). Finally, Ziziphus spina-christi is considered the most important tree for producing honey in the regions where it grows, particularly in the Middle Eastern countries. The honey from this tree is the top speciality and the most expensive honey, selling for up to $\$ 190 / \mathrm{kg}$ (Shenouda, 2004).

Khanbash (2003) tried to estimate the honey yield per Ziziphus spina-christi tree based on the number of colonies kept in selected valleys, the Ziziphus tree density in the valleys, and the amount of honey obtained from the valleys. He calculated the average honey yield as $3.5-5.8 \mathrm{~kg}$ per Ziziphus tree. Moreover, Keasar and Shmida (2009) evaluated the comparative importance of Ziziphus spina-christi and reported that the species secreted a large amount of nectar. However, so far there have been no detailed studies with sufficient sample sizes involving close monitoring of the phenology of the flowers, nectar secretion dynamics, the mass of sugars produced per flower and per tree, and the potential for honey production.

Such studies are very important as a basis for understanding the value of each plant for honey production and for recommending the planting as well as for the conservation of such multipurpose honey plants. In this study, we have determined the amount of nectar sugar secreted per flower and also number of flowers per tree. We used these data to estimate the honey production potential per tree and also per hectare.

\section{MATERIAL AND METHODS}

The study was conducted at the Agricultural Educational Farms of King Saud University, Riyadh, Saudi Arabia, in September 2011 to March 2012, on clear sunny days without rain.

\section{Phenology}

For the phenology study, observations were made on four trees. From each tree, five flower buds (a total of 20) were labeled, and the timing of anther dehiscence, stigma receptivity, and nectar secretion were observed and recorded. The stigma receptivity was determined through monitoring the different stages: greenish, shining, and browning of the stigma tip. 
Monitoring was done using hand lens and stereo binocular microscopes. The flowering stages were determined by observing the flowers every two hours from flower opening until the end of flowering, for four consecutive days.

\section{Dynamics of nectar secretion}

Nectar secretion and its dynamics were determined in two ways. Firstly, to determine whether or not nectar removal initiates more nectar secretion, and also to identify the time of peak nectar secretion, nectar was repeatedly removed and measured. The second experiment involved the measurement of the accumulated nectar at the end of the flowering stage.

Repeated nectar removal and measurement of nectar concentration

For repeated nectar measurements, 19, 16, 19 and 34 flowers from trees 1, 2, 3, and 4 , respectively (a total of 88 flowers buds), were labeled and bagged with bridal-veil netting (Wyatt et al., 1992). The nectar was removed every four hours, during the day only (at $06.00 \mathrm{~h}, 10.00 \mathrm{~h}, 14.00 \mathrm{~h}$ and $18.00 \mathrm{~h}$ ) for two consecutive days. Nectar was collected using Mallick's (2000) washing technique. The microclimatic condition of the study area $(\leq 20 \% \mathrm{RH}$ and mean daytime temperatures of $30-45^{\circ} \mathrm{C}$ ) resulted in rapid evaporation, making the nectar very concentrated and viscous ( $>72 \%$ sugar, g sugar/100 g solution), and leading to rapid crystallization on the surface of the flowers. For these reasons, it was difficult to remove and measure the secreted nectar volume using a micropipette. Similar difficulty in measuring nectar volume using a micropipette has been reported, for example, in Eucryphia lucida (Eucryphiaceae) (Ettershank and Ettershank, 1993). Therefore, to estimate the amount of sugar per flower, $10 \mu \mathrm{l}$ of distilled water was deposited using a calibrated micropipette (Eppendorf Research $^{\circledR}$ ) onto the viscous or crystallized nectar sugar on the surface of a flower. The flowers were handled with care to avoid floral damage and subsequent contamination of the nectar with tissue fluids.
The water was allowed to dissolve the sugar on the surface of the flower. The water was left there only briefly, for about 1 minute, to avoid rapid evaporation and subsequent concentration of the solution. When the solution was recovered, no measurable volume increment was observed because the nectar was mostly very viscous and/or in crystallized form. The sugar dissolved in the distilled water without significant volume change. Like Mallick (2000), we found that the volume recovered was sometimes less than the volume added, because some solution was retained by surface tension on the floral tissues. Since the sugar present dissolved in the whole $10 \mu$ l of water that was added, the concentration of the recovered solution reflects that of the $10 \mu \mathrm{l}$ 'pool' in the flower, and was used to estimate the total sugars present assuming a volume of $10 \mu \mathrm{l}$.

The concentration of the solution was measured using an automatically temperature-compensated, digital handheld refracto-meter (Reichert, Catalog number 13950000, USA). The refractometer was calibrated with distilled water. For each flower and measurement, a new micropipette tip was used. For the repeated sampling procedure, to avoid re-measuring of sugar that might remain from the previous secretion period, after every removal each flower was rinsed/washed three times by adding and removing $10 \mu \mathrm{l}$ of distilled water which was sufficient to lower the refractometer reading to $\approx 0$ or $\leq 1 \%$.

Measurement of nectar concentration in accumulated nectar sample

A total of 120 flower buds $(28,18,14$ and 60 from trees 1, 2, 3 and 4 respectively) were labeled and bagged with bridal-veil netting. The labeled flowers were from the same branches and trees used for repeated sampling. The concentration of sugar in accumulated nectar was measured at the end of the flowering stage (at $18.00 \mathrm{~h}$ on the second day after opening) following the same procedures applied for repeated sampling. 
Determination of the mass of sugar

The mass of sugar in nectar secreted by each flower was calculated from the volume and concentration of the solution measured. For this, the concentration readings (mass/total mass, g sugar/100 g solution) were converted to mass/volume using Weast's (1986) conversion table.

The average amount of honey that can be obtained from a single tree was estimated from the average numbers of flowers per tree and the average mass of sugar per flower, following procedures similar to those of Masierowska (2003) and Kim et al. (2011). Accordingly, all the flower buds were counted in five random areas of $1 \mathrm{~m}^{2}$ of canopy surface per tree on four trees. Then the mean number of flower buds $/ \mathrm{m}^{2}$ was calculated. Flower buds were counted early in the flowering period of the plants, so as not to miss flowers that were shaded. In Ziziphus trees, almost all flower buds appear at once, but flowers open a few at a time. The average number of flowers per tree was estimated by multiplying the average surface area of the canopy by the average number of flower buds $/ \mathrm{m}^{2}$.

The average surface area of the canopy was obtained by measuring 10 Ziziphus tree canopies. Measurement was made manually using a rectangular (2 m x $3 \mathrm{~m})$ wooden frame. The frame was further divided into six equal $1-\mathrm{m}^{2}$ units using grid wire. The small unit areas were used to measure small and irregular surface areas in the canopy. When the canopy was high above the ground, the rectangular frame was fixed to a long stick to reach the height of the canopy. The top surface area $(A)$ of the canopy was estimated by measuring the diameter of the top of the canopy $(=2 r)$ and calculating it as $A=\pi \mathrm{r}^{2}$.

The total mass of sugar that can be obtained from one tree was estimated by multiplying the average number of flowers per tree by the average mass of sugar per flower, and this was used to estimate the amount of honey that can be obtained per tree and per hectare of a Ziziphus forest area. The results were compared among trees, and also between accumulated and repeated nectar collections. Along with these, the environmental factors (relative humidity of the air and air temperature) were recorded.

\section{Statistical Analysis}

To compare the mass of sugar secreted per flower per 4-hour period from the different trees, a repeated measures analysis of variance (ANOVA) was used with 4-hour periods as the repeated measure and trees as a factor (Johnson and Wichern, 2007). Prior to analysis, normality and homogeneity of the variances of the data were checked using Kolmogorov-Smirnov and Levene tests, respectively. Heterogeneity of the variances was eliminated after the square root transformation of the data (Kolmogorov-Smirnov, $P>0.20$; Levene, $P>0.50)$. All tests were performed using Statistica@ (StatSoft, 2010).

\section{RESULTS}

\section{Phenology of flowers}

Generally, most of the flowers of Ziziphus spina-christi were observed to open early in the morning before 06.00 $\mathrm{h}$. The anthers started to dehisce between $06.00 \mathrm{~h}$ and $10.00 \mathrm{~h}$, before the stigma becomes fully receptive. The stigma starts to become shiny and receptive between $14.00 \mathrm{~h}$ and $18.00 \mathrm{~h}$. Then, the stigma becomes brown, as a result of fertilization or aging or the end of receptivity.

Nectar secretion was observed as very tiny droplets starting from $06.00 \mathrm{~h}$ on a few flowers. By $10.00 \mathrm{~h}$, all flowers had started to secrete considerable amounts of nectar and this gradually increased to peak at $14.00 \mathrm{~h}$. During this time, the viscous nectar fully covered the disc in some flowers. As a result of low humidity and high temperatures between $14.00 \mathrm{~h}$ and $18.00 \mathrm{~h}$, the viscous nectar became completely dry and changed into crystalline sugar on the surface of the flowers. Nectar secretion continued up to midday of the second day, but the rate of secretion gradually diminished (Fig. 1). At the end of the second day the flowers generally wilt, but do not fall off. 


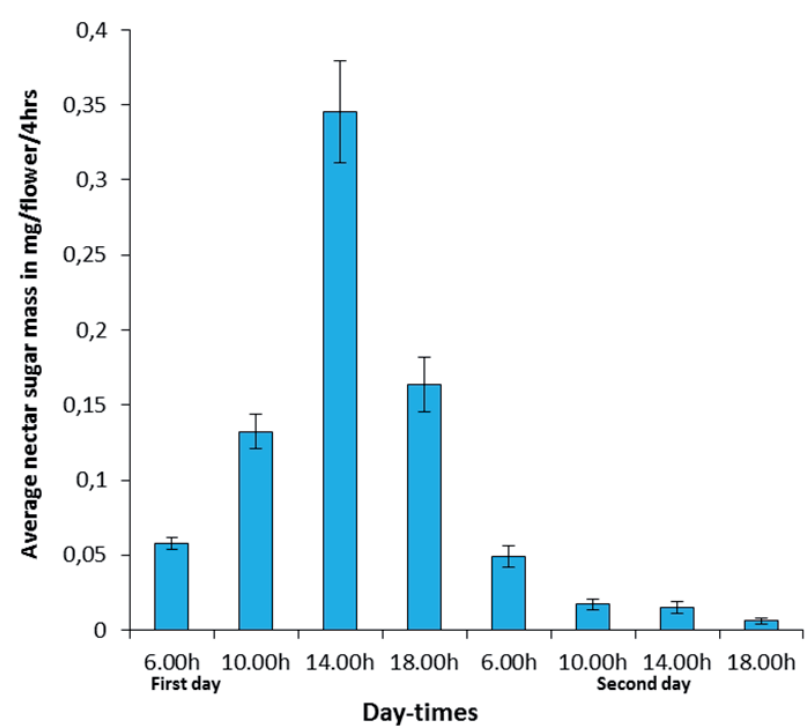

Fig. 1. Average nectar sugar secretion dynamics of flowers of Ziziphus spina-christi trees.

\section{Mass of sugar}

The study revealed differences in the nectar sugar secretion rate among trees and also among flowers within a tree. For flowers from which the nectar was removed every 4 hours, the overall mean ( \pm s.d.) mass of sugar produced per flower was $0.79 \pm 0.54 \mathrm{mg}$ (range $0.09-2.48 \mathrm{mg}$ ). The average nectar sugar values for flowers from investigated trees were $1.43 \pm 0.53 \mathrm{mg}, 0.72 \pm 0.27 \mathrm{mg}$, $0.94 \pm 0.39 \mathrm{mg}$ and $0.37 \pm 0.26 \mathrm{mg}$ for trees 1, 2, 3 and 4, respectively (Tab. 1). The difference in mean masses of sugar among trees was statistically significant $\left(N=88, \quad F_{3,84}=39.44, \quad P<0.0001\right)$. Some trees secreted considerably higher amounts of sugar than others (Fig. 2). There was a significant difference in the mean mass of sugar between the 4-hour periods (repeated measures ANOVA: $\left.F_{7.588}=302.57, P<0.0001\right)$, and a significant interaction effect between trees and 4-hour periods $\left(F_{21,588}=25.02, \quad P<0.0001\right)$. The mass of nectar sugar increases between 10:00 $\mathrm{h}$ and 14:00 $\mathrm{h}$ for trees 1, 2 and 3 but was observed to decrease for tree 4 (Fig. 2) and (Tab. 2).
For the flowers from which the accumulated nectar was collected at the end of the flowering time, the overall average mass of sugar produced per flower was $0.55 \pm 0.23 \mathrm{mg}$ (range 0.06-1.29 mg). The average values for flowers from different trees were $0.69 \pm 0.26 \mathrm{mg}, 0.41 \pm 0.16 \mathrm{mg}$, $0.51 \pm 0.16 \mathrm{mg}$ and $0.53 \pm 0.21 \mathrm{mg}$ for trees 1, 2, 3 and 4, respectively (Tab. 1). The difference in the average mass of sugar among trees was statistically significant $\left(N=120, F_{3,116}=6.56, P<0.0004\right)$. The mean mass of accumulated sugar per flower $(0.55 \pm 0.23 \mathrm{mg})$ was less than the overall mean mass of sugar recorded for repeated nectar removal $(0.79 \pm 0.54 \mathrm{mg})$. This difference was statistically significant $\left(N=208, t_{206}=4.31, P<0.001\right)$.

Honey production potential of Ziziphus

Ziziphus trees have a large canopy and thick branches, and produce huge numbers of small flowers per tree. The average number of cymes $/ \mathrm{m}^{2}$ for a canopy surface was 1873.2 . The average number of flowers per cyme was 23 . So, the average numbers of flowers per $\mathrm{m}^{2}$ of canopy surface was 43,083.6. Since the mean mass of sugar per flower was $0.79 \pm 0.54 \mathrm{mg}$ (from the repeated sampling procedure), the total amount of sugar that 


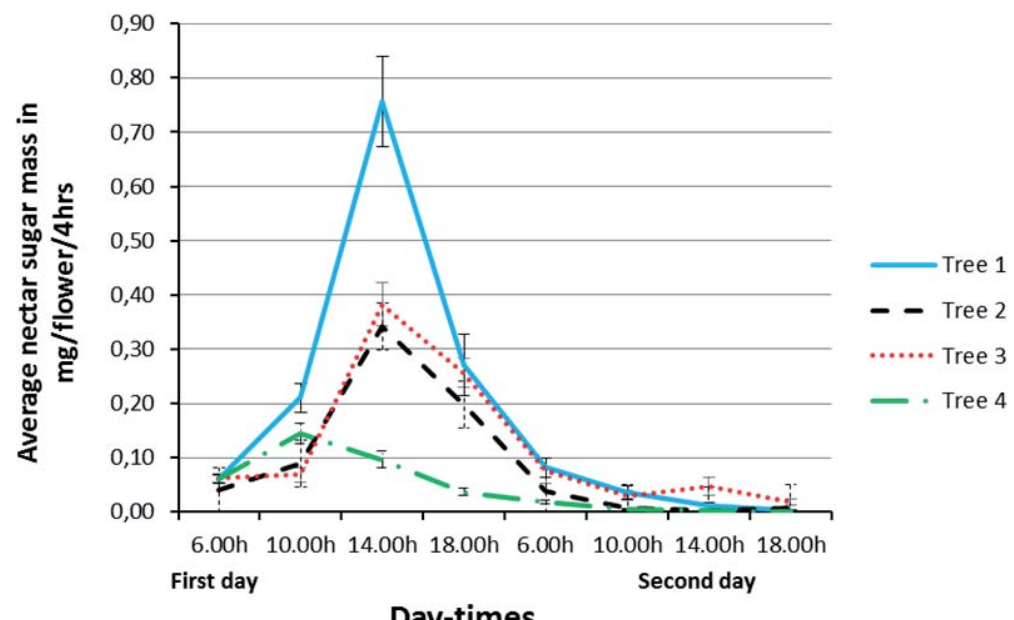

Fig. 2. Mean mass of sugar secreted per 4-hour period from $06.00 \mathrm{~h}$ on the first day of flowering to $18.00 \mathrm{~h}$ on the second day. The four trees are represented by different lines.

Table 1.

Minimum, maximum, mean, and standard deviation of the mass of nectar sugar values of the repeated and accumulated nectar sugar measurement of Ziziphus flowers

\begin{tabular}{||l|c|c|c|c|c||}
\hline Treatments & Trees & $\mathrm{N}$ & Min. & Max. & Mean \\
\hline Repeated & 1 & 19 & 0.80 & 2.48 & 1.43 \\
\hline & 2 & 16 & 0.24 & 1.06 & 0.72 \\
\hline & 3 & 19 & 0.21 & 1.79 & 0.94 \\
\hline & 4 & 34 & 0.09 & 1.05 & 0.37 \\
\hline Total & & 88 & & & 0.79 \\
\hline Accumulated & 1 & 28 & 0.23 & 1.29 & 0.69 \\
\hline & 2 & 18 & 0.55 & 0.71 & 0.41 \\
\hline & 3 & 14 & 0.22 & 0.85 & 0.51 \\
\hline & 4 & 60 & 0.26 & 1.06 & 0.53 \\
\hline Total & & 120 & & & 0.55 \\
\hline \hline
\end{tabular}

Table 2 .

Average nectar sugar mass (mg/flower/4hr) of the four investigated trees in two consecutive days

\begin{tabular}{||l|l|l|l|l|l|l|l|l|l||}
\hline \multirow{2}{*}{ Day } & \multirow{2}{*}{ Hours } & \multicolumn{2}{|c|}{ Tree 1 } & \multicolumn{2}{c|}{ Tree 2 } & \multicolumn{2}{c|}{ Tree 3 } & \multicolumn{2}{c||}{ Tree 4 } \\
\cline { 3 - 10 } & & Mean & S.E. & Mean & S.E & Mean & S.E & Mean & S.E \\
\hline \multirow{4}{*}{$1^{\text {st }}$ day } & 06.00 & 0.06 & 0.01 & 0.04 & 0.01 & 0.06 & 0.01 & 0.06 & 0.01 \\
\cline { 2 - 11 } & 10.00 & 0.21 & 0.03 & 0.09 & 0.01 & 0.07 & 0.01 & 0.14 & 0.02 \\
\cline { 2 - 11 } & 14.00 & 0.76 & 0.08 & 0.34 & 0.04 & 0.38 & 0.04 & 0.10 & 0.02 \\
\cline { 2 - 10 } & 18.00 & 0.27 & 0.06 & 0.20 & 0.03 & 0.26 & 0.03 & 0.04 & 0.01 \\
\hline \multirow{4}{*}{$2^{\text {nd }}$ day } & 06.00 & 0.08 & 0.02 & 0.04 & 0.01 & 0.08 & 0.02 & 0.02 & 0.00 \\
\cline { 2 - 11 } & 10.00 & 0.04 & 0.01 & 0.01 & 0.00 & 0.03 & 0.01 & 0.00 & 0.00 \\
\cline { 2 - 11 } & 14.00 & 0.01 & 0.01 & 0.00 & 0.00 & 0.05 & 0.02 & 0.00 & 0.00 \\
\cline { 2 - 10 } & 18.00 & 0.00 & 0.00 & 0.01 & 0.01 & 0.02 & 0.01 & 0.00 & 0.00 \\
\hline \hline
\end{tabular}




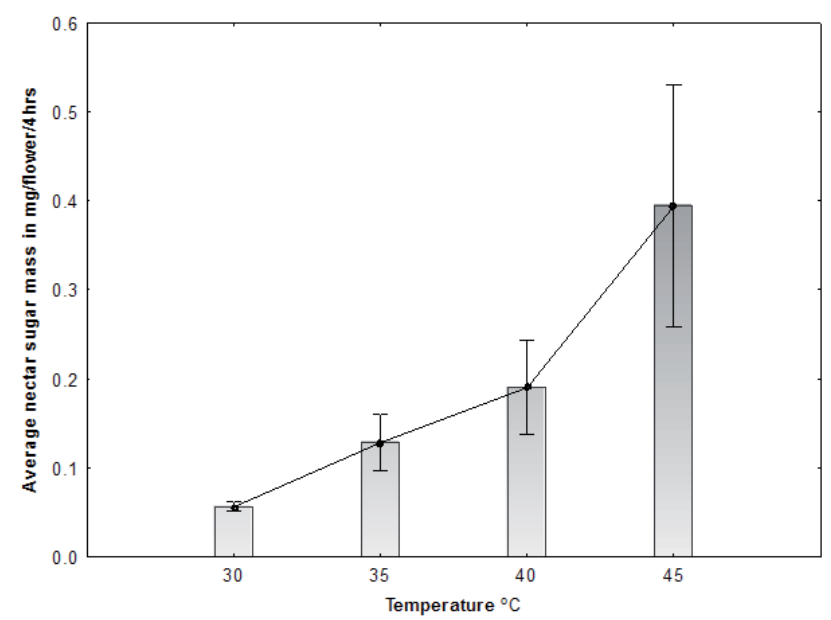

Fig. 3. The relation between the mean mass of sugar secreted per flower in a 4-h period and the mean ambient temperature during nectar sugar collection for the first day of flower opening.

can be produced per $\mathrm{m}^{2}$ of canopy was $34.036 \mathrm{~g}$. The average canopy surface area of a Ziziphus tree was $87.5 \mathrm{~m}^{2}$ (range $52.9 \mathrm{~m}^{2}-125.4 \mathrm{~m}^{2}$ ). Based on this estimate, the average mass of sugar produced per tree was about $2.978 \mathrm{~kg}$ (range $1.80 \mathrm{~kg}$ $4.268 \mathrm{~kg})$.

Given that $1 \mathrm{~kg}$ of honey with $18 \%$ moisture content (wt/wt) contains $820 \mathrm{~g}$ total dissolved sugar, the mean mass of sugar produced by a single tree $(2.978 \mathrm{~kg})$ is estimated to produce $3.6 \mathrm{~kg}$ of honey (range $2.2-5.2 \mathrm{~kg}$ ). Given that the land area required per Ziziphus tree is about $40 \mathrm{~m}^{2}$ considering the required spacing between trees, the total number of Ziziphus trees per hectare of land is about 250 . Therefore, under ideal conditions, the average honey production potential per hectare of Ziziphus forest area per flowering season would be about $900 \mathrm{~kg}$ (range $550 \mathrm{~kg}-1300 \mathrm{~kg}$ ). If there is a rain, the Ziziphus trees flower two times a year (September to November and May to June), so the amount of honey that would be obtained per annum would be much more than the estimated amount.

The effect of environmental factors on nectar secretion

During the study period, relatively low ambient humidity down to $20 \%$ and high day temperatures of $30-45^{\circ} \mathrm{C}$ were recorded. Although it was not possible to assess the effect of these environmental factors by controlling humidity and temperature, under natural conditions peak nectar secretion rates were observed at times when the mean temperature was $45^{\circ} \mathrm{C}$ (Fig. 3). Such high temperatures coupled with low air humidity leads to rapid concentration and crystallization of the nectar on the surface of the flower.

\section{DISCUSSION}

In this plant, nectar secretion starts on the day of the opening of the flower (before $06.00 \mathrm{~h}$ ). Nectar secretion reaches a peak from $10.00-18.00 \mathrm{~h}$, and is observed to continue at a declining rate on the second day after opening (Fig. 1). The relatively extended duration of nectar secretion could be an adaptation of the plant to ensure pollination of flowers by attracting target pollinators.

The rapid crystallization of the nectar sugar is largely attributable to the flower morphology and environmental factors. The flowers of Ziziphus are open discs without a corolla tube. The nectar is freely exposed to external weather factors and particularly to rapid evaporation associated with high temperatures $\left(30-45^{\circ} \mathrm{C}\right)$ and low relative humidity $(20 \%)$. The great 
influence of low humidity and warm and dry conditions on the amount and sugar concentration of nectar was reported by Mačukanović et al. (2004). However, we found no evidence that the rate of nectar secretion was reduced by the high temperatures in the area; there was high nectar secretion during the period of high temperatures (Fig. 3). The presence of a significant positive correlation $(N=16$, $r=0.666, P=0.005)$ between temperature and the mass of nectar sugar secreted in $4 \mathrm{~h}$ periods may indicates the high adaptation of the plant to warm climates (Fig. 3). The heat tolerance of Ziziphus has been reported by Orwa et al. (2009). Petanidou and Smets (1996) reported a positive correlation between all nectar values (i. e. volume per flower, sugar content and concentration) and temperatures in the Mediterranean up to $38^{\circ} \mathrm{C}$ for Thymus capitatus. Crystallization of the nectar on the surface of the flower may negatively affect the efficient collection of nectar by legitimate pollinators including honeybees. As a result, in such high temperatures and low humidity, the amount of nectar available to bees and also the amount of honey that can be obtained would be below the estimated nectar production potential of the Ziziphus plant. In this regard, despite the presence of ample crystalized nectar sugar on the flowers of Ziziphus and also the presence of honey bee colonies near the experimental trees, no honeybees were observed visiting the flowers in the afternoon between $14.00 \mathrm{~h}$ and $18.00 \mathrm{~h}$.

The mean mass of nectar sugar taken from flowers under repeated nectar removal $(0.79 \pm 0.54 \mathrm{mg})$ was significantly higher than the mean mass of sugar available in flowers under accumulated nectar sugar $(0.55 \pm 0.23 \mathrm{mg})$. The variation was significant $\left(N=208, t_{206}=4.31, P<0.001\right)$. This difference could be due to the fact that nectar removal may stimulate further secretion. Castellanos et al. (2002) also found that twice as much as nectar was available in flowers from which nectar was removed periodically than in flowers from which it was not removed.

\section{Honey production potential}

The average mass of sugar secreted per tree $(2.978 \mathrm{~kg})$, and the potential amount of honey that can be obtained from one Ziziphus tree (3.6 kg honey) are relatively high. These values indicate the high potential of the plant for honey production and attraction of pollinators. The actual amount of honey that can be obtained in the hive is expected to be below the estimated amount from this study because (1) when bees collect and transport the nectar to hives they definitely consume a certain amount of sugar for their flight energy and (2) due to its rapid crystallization, all the nectar secreted may not be available to honey bees. The average honey production estimate in this study was interestingly close to Khanbash's (2003) honey yield estimate of $3.5-5.8 \mathrm{~kg}$ per Ziziphus tree. It should be noted, though, that his estimate was based on the number of Ziziphus trees in a given area and the honey yield obtained from honeybee colonies kept in that particular area. The potential of the plant for such a high sugar/honey production is mainly attributed to the richly branched and thick nature of the crown, with a large canopy surface area.

The Ziziphus tree's potential for high nectar secretion could also be due to its flowering pattern. Even though all flower buds appear at the same time on cymes, their flowering pattern is distributed throughout the flowering period - a few flowers/cyme/day for up to two months. This pattern could be due to an adaptation of the plant to get sufficient pollinators for flowers. A few flowers opening per cyme/day rather than too many flowers per cyme/day would minimize pollinator competition among flowers. The Ziziphus tree's extended flowering pattern could also be due to the plant's adaptation to get sufficient sugar for nectar preparation from daily photosynthesis in the leaves. Moreover, the very deep rooted nature of the plant is an adaptation to use deep ground water, so that it can produce nectar without experiencing moisture stress. 
Under ideal environmental conditions, the estimated average amount of honey $(900 \mathrm{~kg})$ that can be obtained per hectare from Ziziphus forest areas is close to the amount of honey reported per hectare for some annual crops and trees like Asclepias syriaca L. (milkweed) (500-600 kg/ha; Zsidei, 1993); Trifolium pratense L. (red clover) with an estimated sugar yield of $883 \mathrm{~kg} / \mathrm{ha} /$ flowering period (Szabo and Najda, 1985), and various Tilia (lime) species (90 - $1200 \mathrm{~kg} / \mathrm{ha}$; Crane et al., 1984).

\section{CONCLUSION}

This study shows Ziziphus spina-christi to be one of the high-potential honey source plants in arid and semi-arid climatic conditions. It was observed, that the nectar secretion of flowers was positively correlated with the ambient temperature of the area indicating the high adaptation of the plant to high temperatures. Based on the amount of sugar estimated to be secreted, the monetary value of Ziziphus honey obtained per hectare of Ziziphus forest can be equal to or greater than the per-hectare monetary value of some crops that require many inputs (seed, fertilizer, labor, disease and pest control expenses). It is worthwhile to plant or to conserve the multipurpose Ziziphus trees both for honey production and for environmental value.

\section{ACKNOWLEDGMENT}

This study was financially supported by the National Plan for Science and Technology (NPST) of King Saud University (project number 11-AGR175002 ). The authors would like to acknowledge NPST for its financial support. Moreover, the authors would like thank Sarah A. Corbet for her valuable comments and editing of the manuscript.

\section{REFERENCES}

Bastiaan M. (1984) - The Sex Life of Flowers. Facts on File Publishers, New York, pp. 110-111.

Castellanos M. C., Wilson P., Thomson J. D. (2002) - Dynamic nectar replenishment in flowers of Penstemon (Scrophulariaceae). Am. J. Bot., 89: 111-118.

Chalcoff V. R., Aizen M. A., Galetto, L. (2006) - Nectar concentration and composition of 26 species from the temperate forest of South America. Ann. Botany, 97(3): 413-421.

Crane E., Walker P., Day R. (1984) Directory of Important World Honey Sources. International Bee Research Association, London, pp. 384.

Ettershank G., Ettershank J. A. (1993) Tasmanian leatherwoods (Eucryphia spp.): floral phenology and the insects associated with flowers, Tasmanian National Rainforest Conservation Program Report no. 11. Forestry Commission, Hobart.

Farkas Á., Orosz-Kovács Zs. (2003) Nectar secretion dynamics of Hungarian local pear cultivars. Plant. Syst. Evol., 238: 57-67.

Galetto L., Bernardello G. (2004) - Floral nectaries, nectar production dynamics and chemical composition in six Ipomoea species (Convolvulaceae) in relation to pollinators. Ann. Botany, 94: 269-280.

Horváth A., Orosz-Kovács Zs. (2004) Individual variability of nectar secretion in the flowers of plum cv. 'Reine-Claude d'Althan. Acta Hortic., 636: 357-363.

Johnson R. A., Wichern D. W. (2007) Applied Multivariate Statistical Analysis, 6th ed., Pearson Prentice Hall, Upper Saddle River, New Jersey, pp. 773.

Keasar T., Shmida A. (2009) - An evaluation of Israeli forestry trees and shrubs as potential forage plants for bees. Israel J. Plant Sci., 57: 49-64.

Khanbash M. S. (2003) - Relationship between the density of Sidir tree Ziziphus spina-christi and honey production. In Preceedings of $3^{\text {rd }}$ Arab Beekeepers Association Conference, Tanta Egypt, 28-31 December 2003, pp. $102-110$ (in Arabic). 
Kim M. S., Kim S. H., Han J., Kang M. S., Park Y. K. (2011) - Honeybee visit and nectar secretion characteristics of the Chinese Hawthorn Crataegus pinnatifida Bunge. J. Apic., The Apicultural Society of Korea, 26(1): 11-14.

Mačukanović M., Duletić S., Jocić G. (2004) - Nectar production in three melliferous species of Lamiaceae in natural and experimental conditions. Acta Vet. - Beograd, 54(5-6): 475-487.

Mallick S. A. (2000) - Technique for washing nectar from the flowers of Tasmanian leatherwood (Eucryphia lucida Eucryphiaceae). Austral. Ecol. 25: 210-212. doi: 10.1046/j.1442-9993.2000.01010.x.

Masierowska M. L. (2003) - Floral nectaries and nectar production in brown mustard (Brassica juncea) and white mustard (Sinapis alba) (Brassicaceae) Plant Syst. Evol., 238: 97-107.

Mohr N. A., Jay S. C. (1990) - Nectar production of selected cultivars of Brassica campestris L. and Brassica napus L. J. Apic. Res., 29(2): 95-100.

Nagy Z. (2002) - Egyre népszerübb növényünk a facélia III. Méhészet, 50(4): 22 In. Nectar production for the Hungarian Honey Industry. Reviewed by Farkas, A. andZajácz, E. (2007) Eur. J.Plant Sci. Biotech.. Global Science Book, pp. $125-151$.

NAS (National Academy of Science) (1980) - Fire wood crops, shrub and tree species for energy production. Board on Science and Technology for International Development Commission on International Relations. Washington, D.C.

Nepi M., Guarnieri M., Pacini E. (2001) - Nectar secretion, reabsorption, and sugar composition in male and female flowers of Cucurbita pepo. Int. J. Plant Sci., 162: 353-358.

Orwa C., Mutua A., Kindt R., Jamnadass R., Simons A. (2009) [online] Agroforestree Database: a tree reference and selection guide, version 4.0. http://www.worldagroforestry.org/treedb2/ AFTPDFS/Zizyphus_spina-christi.pdf (accessed, December 2011).
Pesti J. (1976) - Daily fluctuations in the sugar content of nectar and periodicity of secretion in the Compositae. Acta Agron. Hung., 25(1-2): 5-17.

Petanidou, T., Smets, E. (1996) - Does temperature stress induce nectar secretion in Mediterranean plants? New Phytol., 133: 513 - 518.

Roubik D. W. (1991) - Aspects of Africanized honey bee ecology in tropical America. In: M. Spivak, D. J. C. Fletcher and M. D. Breed (ed.). The African honey bee. Westview Press, Boulder, pp. 259-281.

Scholte P., Khuleidi A. W., Kessler J. J. (1991) - The vegetation of the Republic of Yemen western part. Environmental Protection Council, Agriculture Research Authority, Range and Livestock Improvement Project, Dhamar.

Shenouda R. (2004) - Saudi Arabia's taste for honey, [online] www.fas.usda.gov/info/ agexporter/1998/July\%201998/saudi.html, (accessed February 2012).

StatSoft, Inc. (2010) - STATISTICA, version 10.0, www.statsoft.com.

Szabo T. I., Najda H. G. (1985)-Flowering, nectar secretion and pollen production of some legumes in the Peace River Region of Alberta, Canada. J. Apic. Res., 24(2): 102-106.

Weast R. (Ed.) (1986) - CRC Handbook of Chemistry and Physics, 67 $7^{\text {th }}$ ed., CRC Press, Inc., Boca Raton, Florida.

Wyatt R., Broyles S. B., Derda G. S. (1992) - Environmental influences on nectar productioninmilkweeds(Ascelapiassyriacaand A. exaltata). Am. J. Bot., 79: 636-642.

Zajácz E., Zaják Á., Szalai-Mátray E., Szalai T. (2006) - Nectar production of some sunflower hybrids. J. Apic. Sci., 50(2): 7-11.

Zsidei B. (1993) - Méhészeti ismeretek. Fazekas és fiai nyomdája, Szarvas, in: Nectar production for the Hungarian Honey Industry. Reviewed by Farkas, A. and Zajácz, E. (2007) Eur. J. Plant Sci. Biotech. Global Science Book, pp. $125-151$. 


\title{
NEKTAR Ziziphus spina-christi (L.) Willd (Rhamnaceae): DYNAMIKA NEKTAROWANIA I WYDAJNOŚĆ MIODOWA
}

\author{
Nuru A., Awad A., Al-Ghamdi A., \\ Alqarni A., Radloff $S$.
}

\section{S t r e s z c z e n i e}

Nektarowanie kwiatów Ziziphus zbadane zostało poprzez pobieranie i pomiar nektaru co cztery godziny przez dwa kolejne dni z 88 kwiatów czterech drzew ('wielokrotne pobieranie prób'). Na kolejnych 120 kwiatach tych samych drzew zmierzona była ilość nektaru nagromadzonego na koniec stadium kwitnienia. Jako że nektar szybko krystalizował, do określenia ilości cukru w nektarze pobranym z jednego kwiatu zastosowana została technika wymywania Mallicka (2000). W tym celu na powierzchnię kwiatu $\mathrm{z}$ lepkim lub skrystalizowanym nektarem, skalibrowaną mikropipetą (Eppendorf Research ${ }^{\circledR}$ ), zakroplono $10 \mu$ l wody destylowanej. Stężenie roztworu zmierzono cyfrowym ręcznym refraktometrem. Masa wydzielonych cukrów przez jeden kwiat obliczona została ze zmierzonej objętości i stężenia roztworu. Odczyty stężenia (masa/masa całkowita, g cukrów/100g roztworu) zostały w tym celu przekształcone do wielkości: masa/objętość za pomocą tabeli konwersji Weasta (1986). Średnią ilość surowca miodowego, którą można otrzymać z jednego drzewa, określono ze średniej liczby kwiatów przypadającej na jedno drzewo oraz średniej masy cukrów z 1 kwiatu.

Średnia masa cukrów produkowana przez jeden kwiat, określona za pomocą wielokrotnego pobierania wyniosła $0,79 \pm 0,54 \mathrm{mg} / \mathrm{kwiat}$ (przy wahaniach od 0,09 do $2,48 \mathrm{mg}$ ). Średnia masa cukrów wydzielona przez jeden kwiat dla badanych drzew wyniosła odpowiednio: $1,43 \pm 0,53 \mathrm{mg}$, $0,72 \pm 0,27 \mathrm{mg}, 0,94 \pm 0,39 \mathrm{mg}$ i $0,37 \pm 0,26 \mathrm{mg}$. Różnice pomiędzy drzewami były statystycznie istotne $(N=88, P<0,001)$. Łączna średnia masa cukrów z 1 kwiatu, wyliczona z pomiarów nektaru nagromadzonego, wyniosła $0,55 \pm 0,23 \mathrm{mg}$ (przy wahaniach od 0,06 do $1,29 \mathrm{mg}$ ). Średnie wartości

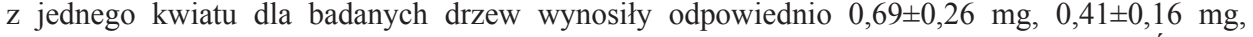
$0,51 \pm 0,16 \mathrm{mg}$ i $0,53 \pm 0,21 \mathrm{mg}$. Różnice te były istotne statystycznie $(N=120, P<0,001)$. Średnia masa cukrów w nektarze, wyliczona $\mathrm{z}$ pomiarów nektaru nagromadzonego, była równa $0,55 \pm 0,23 \mathrm{mg} / \mathrm{kwiat}$. Wielkość ta była istotnie mniejsza od średniej masy cukrów wyliczonej na podstawie wielokrotnego pobierania $(0,79 \pm 0,54 \mathrm{mg} ; N=208, P<0,001)$. Z niniejszych badań wynika, że z jednego drzewa Ziziphus można otrzymać 3,6 kg surowca miodowego (od 2,2 do 5,2 kg), co daje odpowiednio $900 \mathrm{~kg}$ surowca miodowego/ha (od 550 do $1300 \mathrm{~kg}$ ). Wskazuje to na wysoką wydajność miodową tego gatunku. Zaobserwowano również, że wydzielanie przez roślinę nektaru było pozytywnie skorelowane $\mathrm{z}$ temperaturą otoczenia, co wskazuje na jej duże przystosowanie do wysokich temperatur. Wymierna wartość pożytku otrzymanego z 1 hektara lasu Ziziphus może być równa bądź większa od wartości pożytku z niektórych upraw, wymagających dużych nakładów finansowych - koszt nasion, nawozów, pracy, ochrony przed chorobami i szkodnikami. Niniejsze badania wykazały, że w klimacie suchym i stepowym Ziziphus spina-christi jest rośliną miododajną o potencjalnie dużej wartości. Ta roślina o wielu zastosowaniach warta jest nasadzania i ochrony ze względu na produkcję miodu, ale także ze względu na jej znaczenie dla środowiska naturalnego.

Słowa kluczowe: wydzielanie nektaru, roślina miododajna, stężenie cukrów w nektarze, Ziziphus spina-christi. 